Acta vet. scand. $1971,12,151-163$.

From the Department of Pathology, National Veterinary Institute, Stockholm, Sweden.

\title{
A LITERARY REVIEW \\ ON BOVINE FLUOROSIS
}

\author{
By \\ Anna-Lisa Obel
}

The toxic action of ingested fluorine compounds was first observed among people living in places where the fluorine content of the water was high. The clinical picture was dominated by the easily detectable lesions in the enamel of the teeth. Later injury to domestic animals also was found. Bovines have been reported to be more sensitive than man, and they are the most susceptible among the domestic animals, the susceptibility decreasing in the order: Cattle, sheep, rabbits, swine, rats and poultry (Phillips et al. 1955).

The sources of fluorine in cases of bovine fluorosis are several.

1. High fluorine content in mineral supplements.

2. Emission of fluorine-containing gases and dusts from industrial plants.

3. Raised fluorine content in the drinking water.

4. Fluorine-bearing soils deposited upon forage by wind and rain.

The first cases of bovine fluorosis observed were caused by mineral supplements. Rock phosphate contains approximately the same amount of calcium and phosphorus as bone meal but has a considerably lower cost. It is therefore widely used. The product was not usually defluorinated until more recently, when the often very high fluorine content, $2-4 \%$, was recognized. Severe symptoms of fluorosis in dairy herds using raw rock phosphate were reported by Agate et al. (1949), Dale \& Crampton (1955) and Maplesden et al. (1958). Reed \& Huffman (1930), on the basis 
of a 5 year mineral feeding investigation, distinctly warned against feeding raw rock phosphate. In their experiments the cows got badly worn teeth with enamel defects, ankylosis and widespread exostoses.

Fluorosis in cattle due to emission of fluorine-containing gases and dusts from industrial plants is an important and increasing hazard to the livestock in industrialized countries. Cases are described from Norway by Slagsvold (1934) in cows living in farms in the vicinity of an aluminium factory. In the vicinity of chemical factories in Germany with fluorine-containing emissions Cohrs (1941) found typical cases of fluorosis in bovines. Blakemore et al. (1948), and Burns \& Allcroft (1964) reported fluorosis in cattle in farms in industrial areas in England. They found lameness and skeletal changes. The same symptoms were observed by Udall \& Keller (1952) in herds of cattle near aluminium plants in USA.

Fluorosis caused by high fluorine content in the drinking water is more seldom observed than the cases of industrial origin and they usually are not so severe. The risk for this type of fluorosis is of course larger in places where the climate is hot and the water intake high. A contributing factor to the risk is that, according to experimental results, fluorine intake does increase the water intake. Several cases are reported from the USA. In Arizona, Rand \& Smith (1952) observed fluorosis in some farms with a raised fluorine content in the wells. In those farms where the water contained 4.8-5.1 p.p.m. or where the animals spent only part of their lives with a water containing 16 p.p.m. there were no other symptoms than tooth lesions. In another farm with 18 p.p.m. in the drinking water, the cattle showed an unthrifty condition with mild emaciation and lameness. The teeth were mottled and severely worn. Ockerse (1941) found severe tooth lesions in cattle on a farm where the drinking water contained 11.78 p.p.m. fluorine. Neeley \& Harbaugh (1954) found dental lesions but no other symptoms in a herd in Texas, where the water contained 4-5 p.p.m. fluorine. Ezaki (1959) observed enzootic fluorosis in Japan in areas where the drinking water was rich in fluorine. Mottled teeth appeared at the ingestion of at least $0.5-0.6$ p.p.m. of fluorine in the water. No other symptoms were recorded. Murray (1967) diagnosed fluorosis clinically on the basis of tooth and bone involvement in a herd of cattle in Kenya, where the fluorine level in the drinking water was $1.5-$ 
9.2 p.p.m. The affected cattle was in poor condition with low milk production and severe lameness. The incisor teeth showed severe wear and were pigmented and pitted. In some farms in Sweden fluorosis was observed to be caused by a combination of the fluorine content of the mineral supplement and of the drinking water. The symptoms appeared when the farmers began to use new deep-bored wells which had a moderately elevated fluorine content $\left.{ }^{\star}\right)$.

Occasionally fluorosis occurs due to surface contamination of plants, where the soil contains large amounts of fluorine. This is seen in Morocco (Velu 1931, Gaud et al. 1934), where the climate is dry and dusty, and in Tenessee, where animals are grazing on fluorine bearing phosphatic limestone soils (Merriman \& Hobbs 1962).

Also volcanic eruptions could give rise to contamination of the vicinity with fluorine. This has been recorded in Iceland after the eruption of Hekla in 1845, where sheep in the following years showed typical symptoms of fluorosis (Roholm 1937).

It has been of very wide interest to determine the effects of fluoride ingestion on the living animal. When fluoride enters the organism, either per os or parenterally, it rapidly leaves the blood and enters the skeleton and the teeth. It is believed that this is an attempt from the organism to protect the soft tissues from the toxic action. In the bone the fluoride ion substitutes for the hydroxyl ion in the apatite. As this compound is less soluble, fluoride has a stabilizing effect on bone and reduces the susceptibility of enamel and dentine to caries. When $\mathrm{F}^{18}$ was given intravenously in cattle Bell et al. (1961) found that after $240 \mathrm{~min}$. only $4 \%$ of the dose remained in the blood. In experiments with $F^{18}$ Wallace-Durbin (1954) found that the concentration in the skeleton was maximal $4 \mathrm{hrs}$. after the ingestion. In the skeleton the fluorine has a preferential localization to the primary spongiosa beneath the epiphyseal cartilage. Slight deposits also are established under the periosteal and endosteal surface and in places in the trabeculae (Perkinson et al. 1955). When extra fluoride is ingested a part is bound by bone and the remainder is excreted in the urine. If the input later on is diminished, the output of fluoride will exceed the input for a long time, often several years (Largent 1952).

*) These cases will be described in a following publication. 
As the ionic bond between the fluoride and calcium ions in the apatite structure is short and stable, the removal of calcium is rendered more difficult in fluorosis (Havivi \& Guggenheim 1966). This will cause a parathyroid stimulation which is evidenced both in experiments with intraperitoneal lavage with rats (Yates et al. 1964) and by studying the ultrastructure of the parathyroid in lambs with fluorosis (Faccini \& Care 1965).

It has long been known that fluoride has an inhibitory effect on many enzymes. In tissue cultures it has a depressing effect (Berry \& Trillwood 1963, Proffit \& Ackerman 1964). In the effect on bone probably a compensatory mechanism exists through stimulation of the parathyroids, but if the dose is too high, only the depressing effect is seen with the reduction of bone growth (Faccini 1969). Fluoride will also depress the effect of enolase and thereby prevent the glycolysis. Also the lipases are very sensitive. Through affinity to $\mathrm{Mg}$ and $\mathrm{Mn}$ the fluoride might interfere with many enzyme activities. In the blood alkaline phosphatase seems to be raised in fluorosis (Weidman et al. 1959, Miller \& Shupe 1962).

A question of wide practical importance is the tolerance level of fluorine. The toxicity depends upon the solubility of the compound which is administered. When fluoride is given as sodium fluoride it is about twice as toxic as fluorspar $\left(\mathrm{CaF}_{2}\right)$, rock phosphate or cryolite in small doses. When the dose is higher, the difference will increase still more (literature, see Grieser \& Bronsch 1964). In experiments with cattle Greenwood et al. 1964, observed that fluorine in the form of calcium fluoride was less than half as toxic as sodium fluoride or industrial residue fluoride.

Bronsch \& Grieser (1964), made a critical review of the literature on the fluorine toxicity. In several of the experiments in cattle sodium fluoride has been used. In these cases it is not possible to compare the results with other experiments, where rock phosphate is the source of fluoride. When fluorine is given as sodium fluoride or when it occurs in the drinking water the highest tolerable dose was $1-1.5 \mathrm{mg} \mathrm{F} / \mathrm{kg}$ body weight and the toxic dose $1.5-2.5 \mathrm{mg} / \mathrm{kg}$ body weight or equivalent to 40 p.p.m. in the feed. With rock phosphate the tolerance dose was 2.5-3.6 $\mathrm{mg} \mathrm{F} / \mathrm{kg}$ body weight and the toxic dose $5.5 \mathrm{mg} \mathrm{F} / \mathrm{kg}$ body weight or $260-300$ p.p.m. in the feed.

The toxicity of fluoride is also depending on the mineral content in the ration, especially the content of calcium but also of 

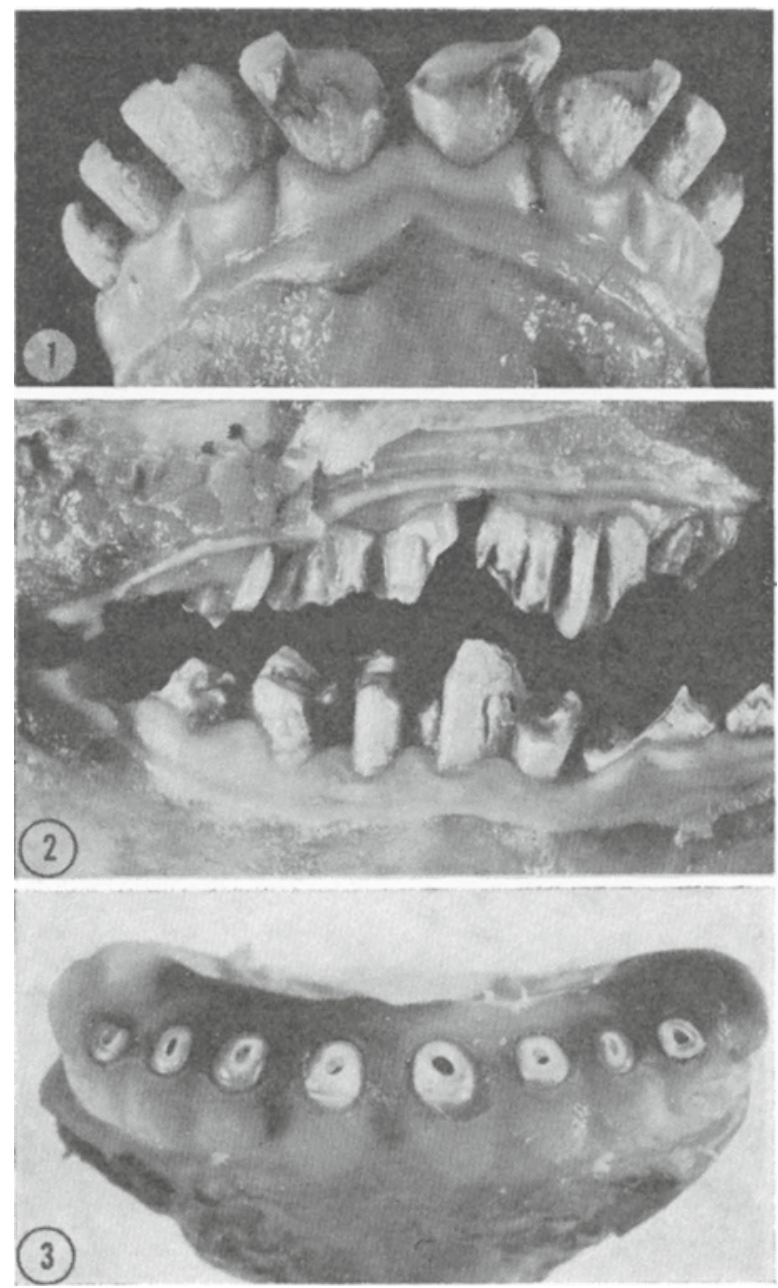

F i g u r e 1. P 4627/62. Fluorosis. Calf. Incisival milk teeth with severe enamel defects.

Figure 2. P 4627/62. Fluorosis. Calf. Molar teeth from the same calf as in Fig. 1. Excessive wear on some of the milk molars with hook formation on the opposite tooth.

F i g u r e 3. P 1685/65. Fluorosis. Calf. The incisival milk teeth are worn down to the gum.

phosphorus. If these minerals are lacking, the tolerance to fluoride is diminished.

In experiments, calcium decreases and molybdenum increases the resorption of fluoride from the gut (literature, see Grieser \& Bronsch). 
When cattle ingests increased quantities of fluoride during the period of tooth development the first lesions occur in the enamel. In the enamel chalky flecks or dark spots and furrows are seen (Fig. 4).

In more advanced cases more or less widespread defects will be found (Figs. 1 and 4). Excessive wear occurs in the incisors, which could be worn down to the gum (Fig. 3), and in the molars. where hooks often arise on the opposite teeth (Fig. 2). When the fluorine content is low, no other symptoms are observed. Mottled or defective enamel is only a sign that fluoride intake was raised during the development of the teeth and says nothing of the actual intake. If the teeth are already erupted, when fluorine is given, the teeth will not show any lesions.

If toxic doses of fluoride are resorbed, stiffness and lameness will follow. It is typical that the lameness is often shifting from one leg to another and it is of intermittent character (Suttie et al. 1958). Fracture of the pedal bone is often described (Allcroft $\&$ Burns 1968). The coat will be rough and dry and the skin tight. In advanced cases the milk production will sink (Dale \& Crampton) and emaciation may follow (Cohrs). Localized hyperostoses occur on the skeleton, especially on the mandible, the ribs, the metatarsals and metacarpals (Fig. 6).

Fluoride has a complex action on the skeleton. With low, repeated doses, as in the cryolite workers, Roholm found osteosclerosis and abundant subperiosteal bone proliferation with ossification in ligaments and joint capsules. The lesions were most prominent in the lumbar spines. Osteosclerosis is a common symptom in man in those places, where the drinking water contains more or less fluorine. Osteosclerosis of the compact bone and excessive proliferation of very dense subperiosteal hyperostoses were also found by Kellner (1939) in experiments with nearly adult dogs, when a small dose of fluorine was given. In long term experiments with rats Röckert \& Sunzel (1960) and Röckert (1963) in microradiograms found osteosclerosis in the spines. With heavier doses of fluoride, as in most of the experimental work and usually in spontaneous cases in cattle, osteoporosis instead of osteosclerosis is a characteristic finding (Figs. 5 and 9 ). Osteoporosis is particularly marked in cattle with fluorosis of industrial origin. In such cases the compact bone is porous and numerous haphazardly localized exostoses are found subperiostally. Also subendosteally there is a lively proliferation 

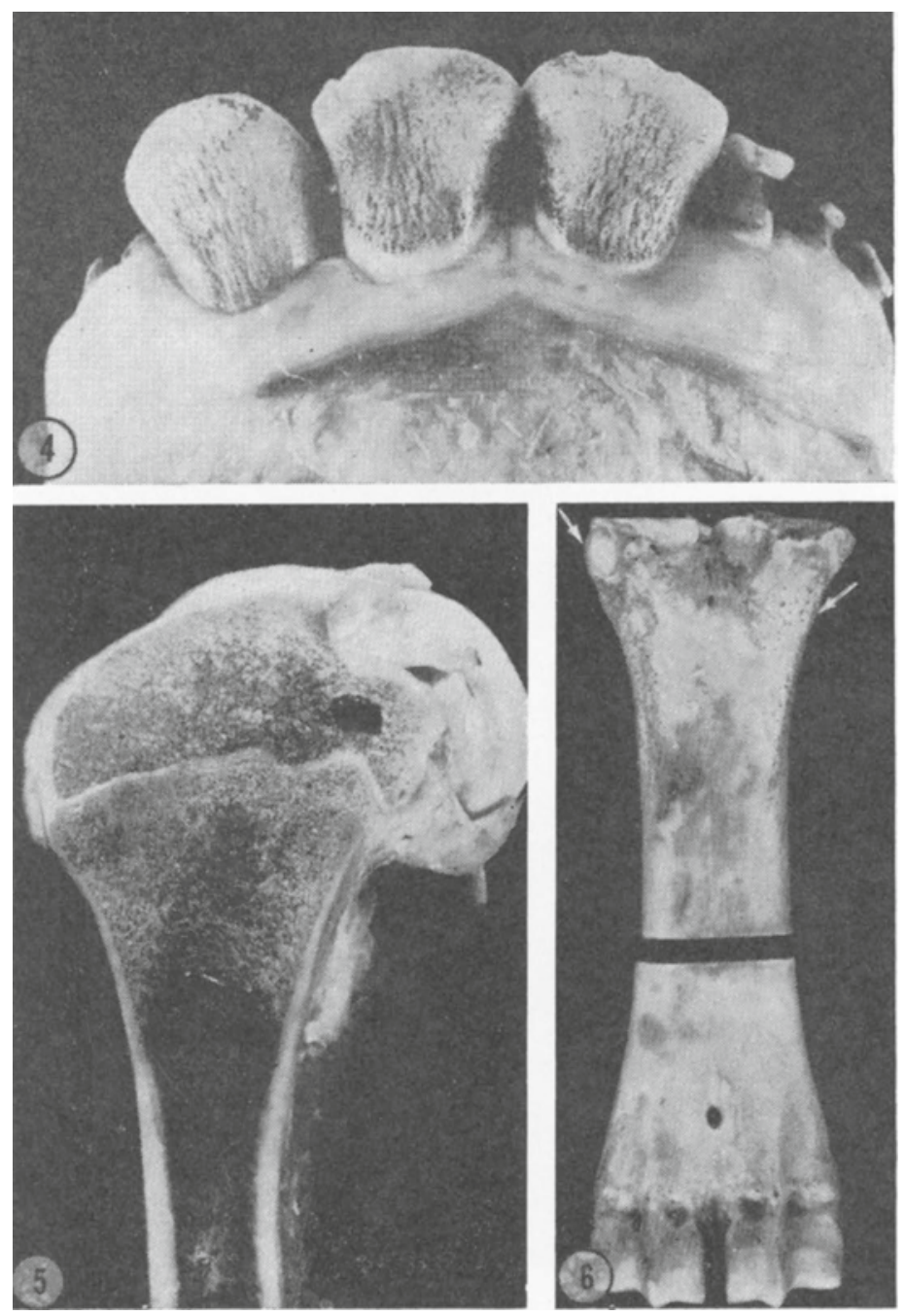

F i g u r e 4. P 729/65. Fluorosis. Bull-calf. The milk incisives have large enamel defects. The permanent incisives have erupted unsymmetrically and have dark furrows in the enamel.

Fi g u r e 5. O 3369/62. Fluorosis. Calf. Femur. Marked osteoporosis. Figure 6. P 729/65. Fluorosis. Bull-calf. Metacarpus. Several exostoses near the carpal joint (top arrow) and rough areas in places on the surface of the bone (lower arrow). 


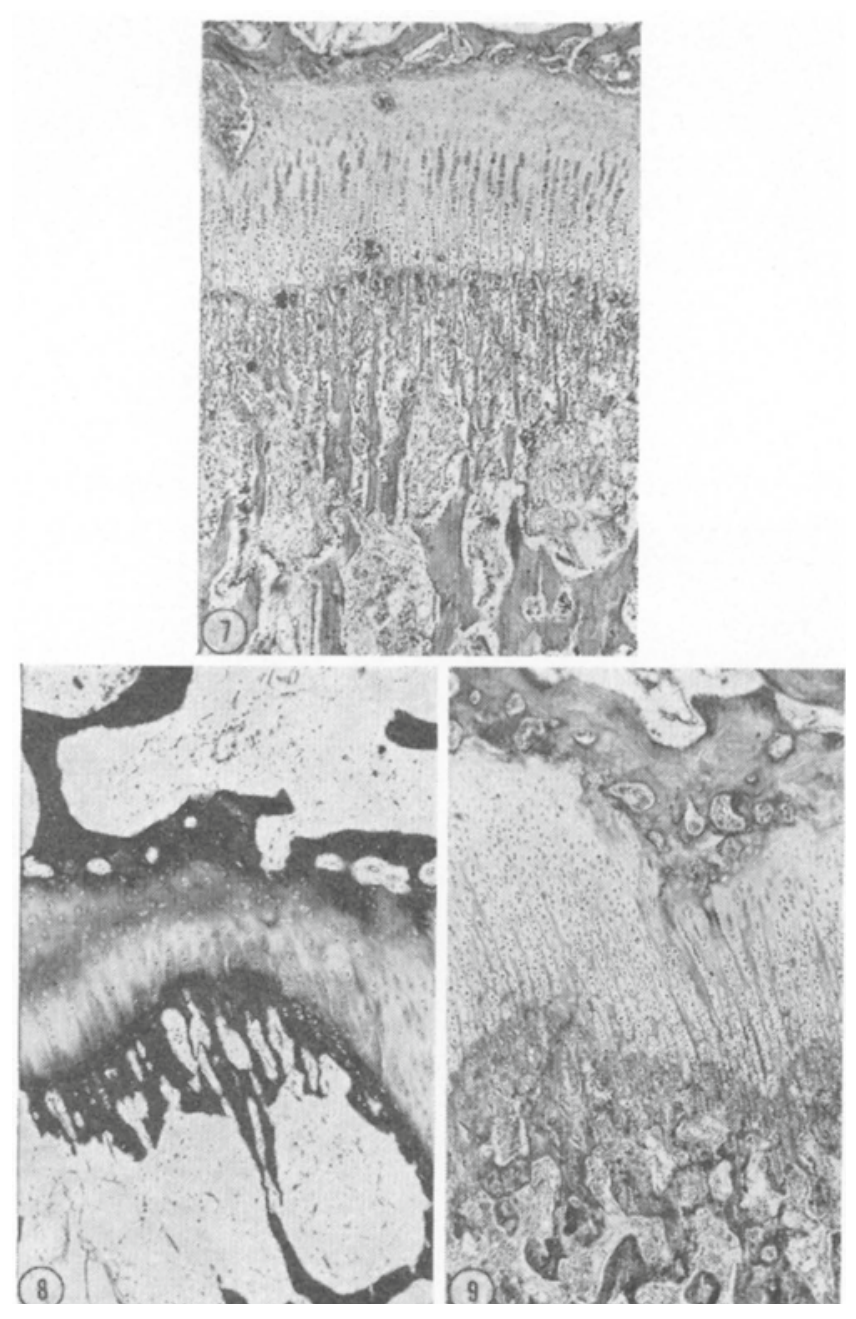

F ig u re 7. Normal epiphyseal line. Calf. Haematoxylin and eosin, $30 \times$.

F i g u r e 8. O 3369/62. Fluorosis. Calf. Epiphyseal line. Strong osteoporosis with insignificant osteoid production on the trabeculae. Haematoxylin and eosin, $30 \times$.

Figure 9. O 1453/63. Fluorosis. Calf. The epiphyseal line is broadened and uneven and with elongated rows of cartilage cells. The spongy bone is osteosclerotic. Large cartilage islands in the trabeculae.

Haematoxylin and eosin, $30 \times$. 

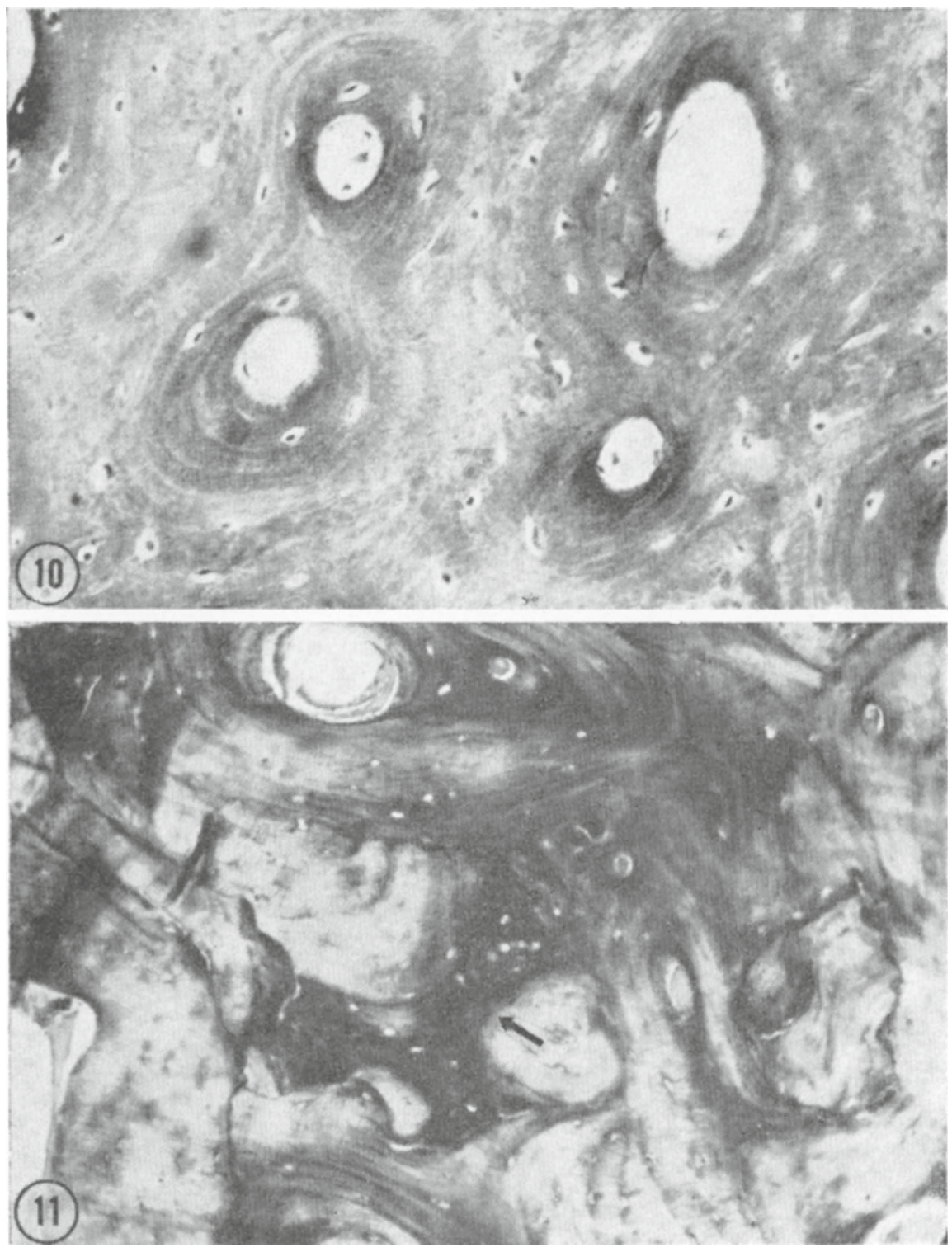

Figure 10 . Normal compact bone. Calf. Concentrically lamellated Haversian systems which are symmetrically placed. Haematoxylin and eosin, $300 \times$.

F ig u r e 11. P 539/63. Fluorosis. Heifer. Compact bone from the mandible. Marked osteosclerosis. The structure is very irregular with woven bone (arrow) alternating with lamellar bone. The calcium content is very uneven and the numerous hyperchromatic lines give the bone a mosaic structure. Haematoxylin and eosin, $150 \times$. 
of new bone. Microscopically Haver's canals are wide and covered with osteoid seams. The osteoclasts may be more or less abundant. The hyperostoses consist of coarsely bundled woven bone which is imperfectly calcified. The bone marrow consists of a fibrillar network poor in cells (Fig. 8). The picture of the lesions is compared with osteomalacia (Lilleengen 1934, Cohrs, Blakemore et al.).

In the studies of fluoride intoxication in experimental animals the bone lesions have been followed in detail (Bauer 1945, Weatherell \& Weidmann 1959). In the cartilage the hypertrophic cartilage cells were more numerous. The length of the cartilage columns was increased (Faccini 1967), (Fig. 8). The capillaries invade the cartilage cells unevenly and with difficulty so that the cartilage border is dented (Fig.9) and isolated islands of cartilage appear. The bone apposition in the primary spongiosa is very meager and the junction of the primary spongiosa and the cartilage is fragile (Fig. 8) (Bélanger et al. 1958). The trabeculae have osteoid seams and the osteoblasts are more numerous in the productive areas. The bone marrow is fibrous and poor in cells. In the compacta Haver's canals are wide with osteoid seams and in places there are resorption cavities with an increased number of osteoclasts. The structure of the bone is often very irregular with lamellar bone interrupted of areas of less differentiated woven bone and there are also variations in the calcium content (Fig. 11). In places the periosteum is thickened and rich in cells and trabecular osteoid tissue is produced. The trabeculae consist of coarsely bundled woven bone. When they mature they get calcified and are later replaced by sclerotic lamellar bone. They are growing at right angle from the bone surface.

Havivi \& Guggenheim have provided evidence that fluoridecontaining bone in mice resists resorption, when they are given injections of parathyroid extract. To maintain the serum calcium at a normal level a hyperactivity of the parathyroid glands will be necessary (Faccini 1967). In fact, the principal lesions in the skeleton in fluorosis correspond with the effect of hyperactivity of the parathyroid glands. A study of the parathyroids in fluorosis has also revealed a picture indicating hyperactivity (Faccini \& Care, Faccini 1967). 


\section{REFERENCES}

Agate, J. N., G. H. Bell, G. F. Boddie, R. G. Bowler, M. Buckell, E. A. Cheeseman, T. H. J. Douglas, H. A. Druett, J. Garrad, D. Hunter, K. M. A. Perry, D. J. Richardson \& J. B. de V. Weir: Industrial fluorosis. A study of the hazard to man and animals near Fort William, Scotland. Memor. med. Res. Coun. (Lond.) 1949, 22, $131 \mathrm{pp}$.

Allcroft, R. \& K. N. Burns: Fluorosis in cattle in England and Wales. Incidence and sources. Fluoride, Quart. Rep. 1968, 1, 50-53.

Bauer, W. H.: Experimental chronic fluorine intoxication. Effect on bones and teeth. Amer. J. Orthodont. Oral. Surg. 1945, 31, 700719.

Bélanger, L. F., W. J. Visek, W. E. Lotz \& C. L. Comar: Rachitomimetic effects of fluoride feeding on the skeletal tissues of growing pigs. Amer. J. Path. 1958, 34, 25-35.

Bell, M. C., G. M. Merriman \& D. A. Greenwood: Distribution and excretion of $\mathrm{F}^{18}$ fluoride in beef cattle. J. Nutr. 1961, 73, 379-385.

Berry, R. J. W.\&W. Trillwood: Sodium fluoride and cell growth. Brit. Med. J. 1963, 2, 1064.

Blakemore, F., T. J. Bosworth \& H. H. Green: Industrial fluorosis of farm animals in England, attributable to the manufacture of bricks, the calcining of ironstone, and to enamelling processes. J. comp. Path. 1948, 58, 267-301.

Bronsch, K. \& N. Grieser: Fluor und Fluortoleranzen in der Ernährung der Nutztiere. (Fluorine and tolerances of fluorine in the food of the domestic animals). Berl. Münch. tierärztl. Wschr. 1964, $77,401-408$.

Burns, K. N. \& R. Allcroft: Fluorosis. Vet. Rec. 1964, 76, 507-509.

Cohrs, J.: Zur pathologischen Anatomie und Pathogenese der chronischen Fluorvergiftung des Rindes. (Pathology and pathogenesis of chronic fluorine intoxication in cattle). Dtsch. tierärztl. Wschr. 1941, 49, 352-357.

Dale, D. G. \& E. W. Crampton: Observations on chronic fluorosis in dairy cattle. Canad. J. comp. Med. 1955, 19, 6-16.

Ezaki, Y.: Studies on enzootic fluorosis in cattle with special reference to mottled teeth. J. Japan vet. med. Ass. 1959, 12, 383-388.

Faccini, J. M.: Inhibition of bone resorption in the rabbit by fluoride. Nature (Lond.) 1967, 214, 1269-1271.

Faccini, J. M.: Fluoride and bone. Calc. Tiss. Res. 1969, 3, 1-16.

Faccini, J. M.\& A. D. Care: The effect of sodium fluoride on the ultrastructure of the parathyroid glands of the sheep. Nature (Lond.) 1965, 207, 1399-1401.

Gaud, M., A. Charnot \& M. Langlais: Le darmous humain. (The human darmous). Bull. Inst. Hyg. Maroc 1934, Nos. I-II.

Greenwood, D. A., J. L. Shupe, G. E. Stoddard, L. E. Harris, H. M. Nielsen \& L. E. Olson: Fluorosis in cattle. Utah Sta. Univ. agric. exp. Sta., Spec. rep. 1964, 17. 
Grieser, N.\& K. Bronsch: Fluor und Fluortoleranzen in der Ernährung der Nutztiere. (Fluorine and tolerances of fluorine in the food of the domestic animals). Berl. Münch. tierärztl. Wschr. 1964, $77,373-379$.

Havivi, E. \& K. Guggenheim: The effect of copper and fluoride on the bone of mice treated with parathyroid hormone. J. Endocr. 1966, 36, 357-361.

Kellner, H.: Histopathologie der Knochen bei chronischer experimenteller Fluorverabreichung. (Histopathology of bone in chronic experimental fluorosis). Naunyn-Schmiedeberg's Arch. exp. Path. Pharmak. 1939, 192, 549-569.

Largent, E. J.: Rates of elimination of fluoride stored in the tissues of man. Arch. industr. Hyg. 1952, 6, 37-42.

Lilleengen, $K$.: Mikroskopisk unders $\emptyset$ kelse av benpreparater fra sauer lidende av kronisk fluorforgiftning. (Microscopical investigation of bone from sheep with chronic fluorine intoxication). Norsk Vet. T. 1934, 46, 68-79.

Maplesden, D. C., I. Motzok, W. T. Oliver \& H. D. Branion: Fluorosis review and field observations. Canad. J. comp. Med. 1958, 22, $427-432$.

Merriman, G. M. \& C. S. Hobbs: Bovine fluorosis from soil and water sources. Univ. Tenessee agric. exp. Sta. Bull. 1962, 347.

Miller, G. W. \& J. L. Shupe: Alkaline bone phosphatase activity as related to fluoride ingestion by dairy cattle. Amer. J. vet. Res. $1962,23,24-31$.

Murray, M.: Fluorosis in a herd of cattle in Kenya. Bull. epizoot. Dis. Afr. 1967, 15, 259-262.

Neeley, K. L.\& F. G. Harbaugh: Effects of fluorine ingestion on a herd of dairy cattle in the Lubbock, Texas, area. J. Amer. vet. med. Ass. 1954, 124, 344-350.

Ockerse, T.: Endemic fluorosis in the Pretoria district. S. Afr. med. J. 1941, 15, 261-266.

Perkinson, J. D., J. B. Whitney, R. A. Monroe, W. E. Lotz \& C. L. Comar: Metabolism of $\mathrm{F}^{18}$ in domestic animals. Amer. J. Physiol. 1955, 182, 383-389.

Phillips, P. H., D. A. Greenwood, C. S. Hobbs \& C. F. Huffman: The fluorosis problem in livestock production. Nat. Acad. Sci., Nat. Res. Counc. 1955, Publ. 381, p. 17.

Proffit, W.D. \& J. L. Ackerman: Fluoride: its effects on two parameters of bone growth in organ culture. Science 1964, 145, 932-934.

Rand, W. E. \& H. J. Smith: The effect upon cattle of Arizona waters of high fluoride content. Amer. J. vet. Res. 1952, 13, 50-61.

Reed, O. E. \& C. F. Huffman: The results of a five year mineral feeding investigation with dairy cattle. Mich. Sta. Coll., agr. exp. Sta., Techn. Bull. 1930, 105.

Roholm, K.: Fluorine intoxication. Thesis. Copenhagen 1937, 364 pp.

Röckert, H.: X-ray absorption and X-ray fluorescence microanalyses of mineralized tissue of rats which have ingested fluoridated water. Acta path. microbiol. scand. 1963, 59, 32-38. 
Röckert, H. \& H. Sunzel: Skeletal lesions following ingestion of fluoridated water. Experientia 1960, 16, 155-156.

Slagsvold, L.: Fluorforgiftning. (Fluorosis). Norsk Vet. T. 1934, 46, $2-68$.

Suttie, J. W., P. H. Phillips \& R. F. Miller: Studies on the effects of dietary sodium fluoride on dairy cows. III. Skeletal and soft tissue fluorine deposition and fluorine toxicosis. J. Nutr. 1958, $65,293-304$.

Udall, D. H. \& K. P. Keller: A report of fluorosis in cattle in the Columbia River Valley. Cornell Vet. 1952, 42, 159-184.

Velu, H.: Relations du Darmous et de la nappe phréatique des zones phosphatees. (Relations between the darmous and the subsoil water in the zones rich in phosphate). Bull. Acad. vét. Fr. 1931, 4, 392-394.

Wallace-Durbin, P.: The metabolism of fluorine in the rat using $F^{18}$. J. dent. Res. 1954, 33, 789-800.

Weatherell, J. A.\&S. M. Weidmann: The skeletal changes of chronic experimental fluorosis. J. Path. Bact. 1959, 78, 233-241.

Weidmann, S. M., J. A. Weatherell \& R. S. Whitehead: The effects of fluorine on the chemical composition and calcification of bone. J. Path. Bact. 1959, 78, 435-445.

Yates, C. S., S. Doty \& R. V. Talmage: Effects of sodium fluoride on calcium homeostasis. Proc. Soc. exp. Biol. (N. Y.) 1964, 115, 1103-1108.

(Received October 16, 1969). 